\title{
THEORETICAL AND PRACTICAL ASSESSMENTS OF TRANSFER PRICES. LEGAL EVIDENCE FROM ROMANIAN CASE LAW
}

\author{
Florin Cornel Dumiter* \\ "Vasile Goldiș" Western University of Arad, Romania, E-mail: fdumiter@yahoo.com \\ Ștefania Amalia Jimon \\ "Vasile Goldiș"Western University of Arad, Romania, E-mail: jimonstefania@yahoo.com
}

(Received: July 2020; Accepted: September 2020; Published: November 2020)

\begin{abstract}
Transfer pricing represents the mainstream agenda in the light of tax law, lato sensu, and international taxation, stricto sensu. At the international level, there can be an emphasis on several problems related to taxation: double taxation, double non - taxation, permanent establishment, business profits, residence criteria, arm's length principle, mutual agreement procedure, dispute resolution of tax conflicts. However, the problem of transfer pricing has more profound judicial and economic implications. The main objective of this paper is to evaluate and assess the underlying features and characteristics of transfer prices in the economical and judicial actual context. The operational objectives are related to a quid pro quo analysis regarding the fine-tuning aspects of transfer pricing in the digital taxation era. The case law presented in this article tackles the main problems of applying transfer pricing international regulation upon Romanian tax jurisprudence. The conclusion of this article highlights the need, mutadis mutandis, for a tax policy agenda revealing a strengthened fiscal and financial environment towards the creation of a new proper fiscal space.
\end{abstract}

Keywords: International taxation, business profits, permanent establishment, advance pricing agreements, Romanian jurisprudence.

\section{Introduction}

Transfer prices are a new institution of national and international tax law. However, transfer prices are a mysterious field, with many "unknowns", with complex issues involving solid knowledge of corporate law, commercial law, national and international tax law, finance and taxation, financial management, insolvency. The implications of transfer prices are related to transactions that take

\footnotetext{
${ }^{*}$ Corresponding author: Florin Cornel Dumiter. E-mail: fdumiter@yahoo.com.
} reproduction in any medium, provided the original author and source are credited. 
Dumiter, F.C., Jimon, Ș.A. (2020)

Theoretical and practical assessments of transfer prices. Legal evidence from Romanian case law

place between different companies, targeting, in particular, those control prices that are set up for different business purposes, but, in particular, in order to determine the tax base.

The main problem in transfer prices is the complex and complicated structure of a corporation in terms of shareholders and associates, as well as the corporate management of a company operating across borders. The rules regarding transfer prices occur when there are market frictions about the conduct of operations within the same corporate structure so that the economic environment should not be manipulated, influenced, or directed in less orthodox corporate transactions. The market price principle (Arm's length principle) is a quid pro quo regarding the application of these transfer price rules on the market.

Multinational companies (SMEs) can use the instrument called transfer prices to divert a part of their profits to those tax jurisdictions that practice low taxation rates. In order to strengthen the taxpayer's compliance and tax behavior, tax authorities of various states apply different rules regarding transfer prices in a manner that requires the taxpayer to prepare complex and comprehensive tax documentation to be consistent $v i s-\dot{a}-v i s$ of national and international transfer prices law.

Based on numerous debates and discussions with tax authorities from different countries, in 2013, the OECD published a BEPS Report (Base Erosion and Profit Shifting) through which could be made a strong connection between BEPS and the complex structures of a multinational company. The 15 actions of the BEPS project targeted transfer pricing. It is particularly important to note that in addition to actions $8,9,10$, and 13, which initially concerned transfer prices, action 14 "the mutual agreement procedure" (MAP) was subsequently set up and aimed the establishment of a framework through which governments, lato sensu, and tax authorities, stricto sensu, can be aware of transfer prices disputes.

Tax compliance, tax behavior and tax culture are key elements regarding the application of tax legislation at national, European and international levels. Given this compliance with the rules imposed by the tax authorities, multinational companies must develop and implement a coherent strategy on transfer prices management, in order to justify and certify the decisions regarding the correct setting and adjustment of transfer prices. To this purpose, taxpayers will have the administrative and legal prerogative to solve the disputes arising from the application of transfer prices rules.

In view of the above-mentioned aspects, the Mutual Agreement Procedure (MAP) is particularly important for resolving tax disputes in order to avoid international double taxation. The issue of double legal and economic taxation remains a problem faced by the European Union in order to eliminate dual taxation, but also to create fair and equitable taxation of taxpayers. Also, the rules on Advance Price

2 Journal of Legal Studies Volume 26 Issue 40/2020

$S$ sciendo ISSN 2457-9017; Online ISSN 2392-7054.

Web: publicatii.uvvg.ro/index.php/jls. Pages $1-18$ 
Dumiter, F.C., Jimon, Ș.A. (2020)

Theoretical and practical assessments of transfer prices. Legal evidence from Romanian case law

Agreements (APAs) give the taxpayer the prerogative that in the country where such rules are established, he can negotiate a common agreement to resolve the disputes between taxpayers, on the one hand, and tax authorities, on the other hand. Transfer prices are the element of national and international tax law that presents the highest tax risk because it supposes a less objective application of the rules established by law, involves tax authorities in different countries, all of these are subject to the risk of transfer of different prices. The risks associated with transfer prices are mainly related to the high volumes of revenue found in each foreign tax transaction. Therefore, given the difficulties of the contemporary economic period, the tax authorities of different countries at the European level are oriented towards specific problems of transfer prices.

Regarding the financial aspects of transfer prices, the financial crisis of 2007-2009 which had affected the financial services industry and the global economy significantly influenced the way the market price principle was applied (Arm's length principle). As a result, commercial banks have restricted and tightened lending conditions, while multinational companies have intensified their crossborder inter-company transactions, generally having only their resources at their disposal. At the same time, we can notice an inverse connection manifested between the transfer price policies of multinational companies and the sustainable lending policies of the financial market. This situation has led to the consolidation and promotion of credit risk management by financial companies.

The financial crisis of subprime loans has intensified and tightened transfer prices policies regarding the establishment of stable credit rates in different states and regions, given that the financial market has required additional financing costs from companies for their development.

Since at international level is a trend towards the adoption of transfer prices documentation rules, it can be noted a significant intensification of the volume and transactions of intra-group international trade, but also a much more severity in the controls established by tax administrations, which led to a sharp increase in the costs of voluntary compliance of taxpayers. However, frequently, tax administrations of different states consider the transfer pricing documentation to be only informative, as it is not appropriate to place taxes and fees in accordance with the risks associated with them.

The structure of this article is as follows: the first section contains introductory notions regarding the importance of transfer prices analysis, presenting current legal and economic issues in the context of globalization and digital economy; the second section presents the current state of research in this field, in which it is analyzed the main opinions of recognized specialists in the field; section 3 creates the analytical and synthetic framework for the presentation and analysis of transfer prices in three ways: economic, legal and technical; the fourth section presents an 
Dumiter, F.C., Jimon, Ș.A. (2020)

Theoretical and practical assessments of transfer prices. Legal evidence from Romanian case law

important case study from the jurisprudence of transfer prices in Romania; the last section deals with the conclusions and final considerations of the study, which also presents the main current and future challenges of transfer prices.

\section{Literature review}

The evolutions regarding the conceptual and methodological framework of transfer prices were analyzed by the need to implement new efficient ways of financial reporting of tax obligations, a necessary foundation to strengthen the capacity of tax authorities to conduct complex audits in the field of transfer prices. Increasing the quality of tax information obtained by tax authorities in reporting is an essential and unequivocal element in the analysis of large taxpayers (Gouthiere, 2015).

Glahe (2013) makes a careful analysis of the correlations between transfer prices and the fundamental freedoms of the EU. The conclusions of this study suggest that the discretionary national rules that occur in transfer prices in the application of the market price principle (Arm's length principle) must fulfill several specific requirements and eloquent legal aspects to be justified.

Sim (2013) highlights in the study the implications of transfer prices in financial services. In this regard, in this study, the author analyzes important issues such as costs of audit operations, payments on managerial investments, and the quality of different types of guarantees.

Another important aspect is the development of knowledge-based management in transfer prices. Rossing \& Pearson (2014) argue the need to introduce an integrated knowledge-based management system having as a foundation the defining elements of transfer prices. These aspects would lead to the strengthening of transfer price documentation, as well as to the improvement of the capacity to collect information and historical data.

The application of transfer prices in the logistics sector is based on the establishment of different business models applied in this sector. Bilaney (2014) analyzes different methodologies attached to transfer price models applied in the logistics sector. The author argues that there are three defining models of transfer prices that can be successfully applied in business, given the implications of globalization, as well as the rapid changes that have taken place in this sector.

Koomen (2015a) analyzes transfer prices under the auspices of BEPS and from the perspective of restructuring the market price principle (Arm's length principle) by conducting a genuine historical analysis of the implementation of this initiative by the OECD. In this study, the author performs a comparative analysis of the application of transfer prices in practice, in this regard the study presenting numerous case studies on different jurisdictions.

Koomen (2015b) introduces the need to increase the substance and the implications of the market price principle (Arm's length principle) from the perspective of the

4 Journal of Legal Studies Volume 26 Issue 40/2020

$\checkmark$ sciendo ISSN 2457-9017; Online ISSN 2392-7054.

Web: publicatii.uvvg.ro/index.php/jls. Pages $1-18$ 
Dumiter, F.C., Jimon, Ș.A. (2020)

Theoretical and practical assessments of transfer prices. Legal evidence from Romanian case law

OECD initiative by introducing the BEPS project. The study includes the introspective economic analysis and presents several case studies from different jurisdictions, and at the end of it, are made recommendations, under the auspices of bringing amendments to Art. 9 of the OECD Model Convention.

An interesting study on the final report of the 8 BEPS Action Plan is the one established by Wright et al. (2016). In this study, the authors made commentaries from the perspective of economists regarding the application of action 8 of the BEPS project on multinational companies. Also, other important aspects discussed and analyzed in this article are those regarding the practical application of the provisions on intangible assets, functional analysis, methods and techniques of analysis of the transfer prices.

Rossing et al. (2016) perform a comprehensive analysis of transfer prices from the perspective of strategic concepts of controlling. The authors conclude that it is imperatively necessary to introduce different types and structures of managerial control to increase, from the perspective of multinational companies, the quality of the implementation of strategic practices on transfer prices.

The application of transfer prices in the post-BEPS era highlights the need for the OECD to continuously improve the conceptual, methodological and practical framework for transfer prices to create an international tax framework that is as fair and equitable as possible. In this regard, it should be undertaken actions and activities targeting international cooperation, the exchange of information and policies leading to an increase in social welfare and living standards (Storck et al., 2016).

Stana \& Țurlea (2017) realize an economic analysis of transfer prices from the perspective of estimating the risks related to large taxpayers in Romania. The results of this study propose a model through which a company can identify the risks associated with transfer prices through a method of analysis and measurement as complex and detailed as possible.

A comprehensive analysis of the literature on risks and transfer prices framework in multinational companies is conducted by Buus (2018). In this study, the author captures several key aspects regarding the value of intangible assets, the strategic functions of the units of multinational companies. Also, it is approached aspects regarding transfer price risks and profit allocation between the parent company and its subsidiaries and branches.

Dumiter \& Boiță (2017) argue that the whole framework of transfer prices both nationally and internationally requires considerable improvements. The complex problems faced by tax administrations, taxpayers, and economic and legal practitioners call for the need of holistic approaches by all involved actors to find viable solutions to improve transfer prices rules, both at the national level of the 
Dumiter, F.C., Jimon, Ș.A. (2020)

Theoretical and practical assessments of transfer prices. Legal evidence from Romanian case law

different countries, as well as at the level of the international framework, respectively at the level of the European Union.

Dumiter \& Jimon (2018) highlight the fact that Romania's example comes to support the "path" that must be followed by the states that are in the process of "catching up" vis-à-vis the market economies of developed countries. Similar to the other economic and legal systems of Central and Eastern European countries, Romania has taken important "steps" in improving the national tax law framework to provide greater harmonization with European tax policy. Moreover, the capacity of tax administrations has been significantly improved both in terms of how they interact with taxpayers and in terms of creating a state-taxpayer partnership so that the tax authorities have also a role of consultation, advising, and catalyst for the smooth running of the economy.

\section{Judicial, economic, and technical features of transfer prices}

In this section, transfer prices will be approached and analyzed from three perspectives: (i) a legal perspective on the legislative implications by analyzing both the national and international framework; (ii) an economic perspective of the financial aspects, highlighting the aspects related to the current economic practices; (iii) a technical perspective of transfer prices with methodological aspects of transfer prices documentation, as well as the correct determination of prices and costs.

\subsection{Judicial implications}

Fiscal audits are performed by the authorities to increase the amount and level of revenues mobilized to the state budget. In cases where tax authorities undertake transfer prices oriented financial audit actions, they often impose interest and penalties in certain situations. Therefore, we must specify that an audit of transfer prices is carried out at a certain regular interval of time, which implies a period of 2 - 5 years. This audit can also be generated by situations where there has been an automatic exchange of information between certain states.

In cases where a dispute arises, the chances of success may differ from one court to another, as well as from one country to another. Also, professional judgment may in some cases be influenced by certain attitudes such as the current concern about multinational companies that divert profits from high taxation jurisdictions to low taxation jurisdictions. Worth mentioning in these cases is the cost of litigation which involves hearing various witnesses and specialists, tax and accounting expertise, expertise on transfer pricing.

One of the alternatives to the dispute is the mutual agreement procedure under the auspices of art. 25 of the OECD Model Convention and tax arbitration based on the EU Arbitration Convention. In cases where the mutual agreement procedure is

6 Journal of Legal Studies Volume 26 Issue 40/2020

$\checkmark$ sciendo ISSN 2457-9017; Online ISSN 2392-7054.

Web: publicatii.uvvg.ro/index.php/jls. Pages $1-18$ 
Dumiter, F.C., Jimon, Ș.A. (2020)

Theoretical and practical assessments of transfer prices. Legal evidence from Romanian case law

placed "beyond" the national law of the states and is intended to resolve and eliminate the pressing problem of international economic and legal double taxation based on the application of international tax treaties, the issue of arbitration generally refers only to adjustments regarding transfer prices.

The mutual agreement procedure is opened at the initiative of the taxpayer, who, as a first step, requests the competent authority. As regards the period of initiation of the mutual agreement procedure, it shall be limited to a period of 3 years from the first notification of the action specifying that the taxation was not made under the auspices of that tax treaty. It should be noted that, in the majority of cases, this first notification involves a formal request for the collection of a certain tax. If the tax is perceived as a deduction established at source, the period of 3 years starts from the moment of the actual payment of this tax, unless the taxpayer proves that he was notified of this deduction at a later date.

The competent authorities, following receipt of the above specific request, will properly analyze this request. It should be mentioned that the aspects that the competent authorities will take into account as particularly important are: is the tax treaty in question the subject of the respective transaction?; is the request sent within the legal deadline?; are the objections justified?.

If the mutual agreement procedure does not resolve the case, the new paragraph 5 of art. 25 stipulates that unresolved issues may be addressed to arbitration within a maximum of 2 years from the submission of the case to the competent authority of that state. In certain situations, the arbitration procedure is described under the auspices of art. 25(5) is not permitted or restricted to certain specific cases, due to certain national tax issues or administrative practices of certain states.

\subsection{Economical aspects}

From an economic point of view, transfer prices represent the value that is used for a product, asset, or service by a company and that it sends to another party or segment of the same company. The economic reason that is the basis of a transfer price is the ability to assess the performance of a group of economic entities. In this sense, the concept of corporate governance regarding multinational companies in all sectors of the economy: banking, pharmaceuticals, automotive, and electronics, which establishes a price to be monitored within the risk management department. Also, transfer prices can be seen as an active component of the management control system of a multi-division company, with the aim of developing a sustainable system for quantifying and evaluating risk and performance.

The managers of a group of economic entities want to set prices for goods and services within a group in order to establish the sale or purchase of these goods and services outside the above-mentioned group. From a financial point of view, transfer prices are allocated in the most comprehensible way possible for different 
Dumiter, F.C., Jimon, Ș.A. (2020)

Theoretical and practical assessments of transfer prices. Legal evidence from Romanian case law

segments of the group. Another important aspect to mention is the negotiation within a certain group of entities of the profit structure. This aspect is economically desirable and must be applied from a fiscal perspective as well.

The reason behind the establishment of a transfer price between affiliated entities, in terms of intra-group goods and services, is the ability to quantify the individual performance of these economic entities within a multinational group. Due to the fact that, within a multinational corporate group, individual entities are treated separately in terms of costs, profits and investment centers, transfer prices are the sine qua noncondition for substantiating the economic and financial performance of entities from the perspective of managerial accounting.

The term transfer price is often used in a pejorative manner and refers to taxable income that is misappropriated by a company belonging to a multinational group and located within a tax jurisdiction that charges high taxes to a company belonging to the same group but which is located within a tax jurisdiction that practices low taxes, through an incorrect transfer price, to reduce the overall tax burden of the group of economic entities.

Indeed, transfer prices provide opportunities for multinational companies to divert some of their profits from a state with high taxation to a state with a low corporate tax rate and certain deductions for various activities. However, it should be noted that tax planning is one of the options to be considered by multinational companies. Analyzing current economic practices, it can be noted that large groups of entities prefer to maintain a cordial relationship with tax authorities of different states during their activities. Certainly, the volume of taxes paid is an absolute priority for large companies, which practice a well-documented transfer price policy in order to develop a successful business model.

The above points lead to the conclusion that only a small change in transfer prices regarding a high volume of exports of goods and services can lead to a significant difference in the tax base of a state. Therefore, under the auspices of the tax legislation of many states, the tax administration has the prerogative to review and adjust accordingly the transfer prices of taxpayers in determining income tax.

In the process of the adjustment of transfer prices, a tax authority shall have the prerogative to reallocate the revenue belonging to the associated undertakings on the basis of the results of the application of the market price. Indeed, certain tax authorities may reallocate income from an affiliated undertaking to its taxpayer in the form of transfer price adjustments.

\subsection{Technical assessments}

In terms of technical aspects, these concern international financial transactions that must be carried out under the auspices of tax optimization, due to the various divergent objectives of the national laws of most states. From the point of view of

8 Journal of Legal Studies Volume 26 Issue 40/2020

$\checkmark$ sciendo ISSN 2457-9017; Online ISSN 2392-7054.

Web: publicatii.uvvg.ro/index.php/jls. Pages $1-18$ 
Dumiter, F.C., Jimon, Ș.A. (2020)

Theoretical and practical assessments of transfer prices. Legal evidence from Romanian case law

capital mobility that is used by a company, its tax rate may differ depending on the specific tax positions of the groups of companies. From this perspective, we distinguish (i) companies located in tax jurisdictions that have favorable tax regimes; (ii) companies located in tax jurisdictions that practice special regimes applied to groups of companies; (iii) loss-making economic entities.

In order to analyze a company from the technical perspective of transfer prices, several special facets must be considered. Firstly, a sectoral analysis of the industry to which it belongs and in particular of the sector of activity; stress-tests on the financial modeling of the borrower's financial capacity; a credit scoring analysis to determine the specific conditions for contacting the loan. Secondly, it must be determined, on the basis of the market price principle, the price of the transaction in question; in this sense, the determination of the interest rate will be considered based on the market price principle, based on the CUP method, but other important elements will be taken into account such as credit risk, the social and economic capacity of the debtor, contractual conditions. Thirdly, it must be drawn up the economic-financial analysis of the company, the concrete way of running and coordinating the business, the business model, the company's forecasts and projections, as well as the cash flow. For this purpose, the SWOT analysis has a unified and integrated approach, structured in four parts: (i) strengths - the way in which the company has advantages and prerogatives to be above competitors; (ii) weaknesses - which are the main segments of the business in which the company is not at the level of competitors; (iii) threats - what are the causes that can lead to a decrease in the company's operating profit; (iv) opportunities - what are the company's development prospects through which it can generate added value.

The most important point is the implementation of financial analysis and financial modeling. During the financial analysis of the company, must be analyzed the information provided from its annual financial statements. It is also important to analyze the capacity in which the company can meet its maturity obligations. Moreover, the financial analysis must aim the borrower's ability to ensure secure and stable cash flow, sufficient to pay interest and rates at the maturity of the loan. These criteria must cover the following financial indicators: (i) liquidity - which refers to the debtor's ability to repay debts at maturity; (ii) solvency - the debtor's fulfillment of long-term financial obligations and the payment of all installments due.

Hybrid financing is important because it is a symbiosis between equity and debt. Combining their characteristics can lead to distortions of tax law between two states, leading, mutatis mutandis, to certain tax advantages. Trade arguments are also particularly important since hybrid financing is used in circumstances where country investment risk involves a reduction in invested capital, automatically generating certain gains in the form of profit. 
Dumiter, F.C., Jimon, Ș.A. (2020)

Theoretical and practical assessments of transfer prices. Legal evidence from Romanian case law

Among the types of hybrid financing, we mention the preferential shares that imply the prerogative of both the increase of the profit and some fixed dividends; bonds convertible into shares or other financial instruments; other complex financial instruments, for example, various participations in a company's profits.

4. The case: A SRL versus DRFP Brasov regarding the implications of transfer prices upon the taxation of additional profit and accessories as delay increases and interests

In this section, it was made the presentation and analysis of a case of the High Court of Cassation and Justice of Romania (HCCJ) - Administrative and Fiscal Litigation Section. Decision no. 1856 of 20 April 2020 issued by the HCCJ considers the settlement of the appeal filed by the appellant-plaintiff SC A. SRL against the Sentence no. 14 of February 4, 2016, pronounced by the Târgu Mureș Court of Appeal, Civil Section II of administrative and fiscal contentious, in File no. x / 2013 having as object the contestation of the decision of the General Directorate of Public Finances of Mureș County of taxation regarding the additional fiscal payment obligations representing additional established profit tax, plus accessories consisting of increases and interests, and other penalties (High Court of Cassation and Justice of Romania, Administrative and Fiscal Litigation Section, Decision No. 1856, pronounced in public session on April 20, 2020).

\section{Circumstances of the case}

The plaintiff SC A. SRL, in contradiction with the defendant, Regional Directorate of Public Finances of Brașov (DRFP Brașov), requested the Târgu Mureș Court of Appeal to partially cancel the Decision no. 51 of June 21, 2013, issued by the defendant through which is rejecting the plaintiff's appeal regarding the Fiscal Inspection Report no. $\mathrm{x}$ of December 18, 2012, which established additional tax obligations in the form of income tax and accessories consisting of increases and interest, as well as other penalties, in the total amount of RON 1,038,774.

\section{The solution of the court of the first instance}

The action brought by the plaintiff SC A. SRL, in contradiction with the defendant DRFP Brașov regarding the partial annulment of Decision no. 51 of June 21, 2013, issued by the defendant was admitted by the Târgu Mureș Court of Appeal, civil section II of administrative and fiscal contentious.

By Sentence no. 14 of February 4, 2016, Târgu Mureș Court of Appeal decided to partially cancel the Decision no. 51 of June 21, 2013, issued by the defendant DRFP Braşov by which the plaintiff's appeal regarding the Fiscal Inspection Report

10 Journal of Legal Studies Volume 26 Issue 40/2020

$\checkmark$ sciendo ISSN 2457-9017; Online ISSN 2392-7054.

Web: publicatii.uvvg.ro/index.php/jls. Pages $1-18$ 
Dumiter, F.C., Jimon, Ș.A. (2020)

Theoretical and practical assessments of transfer prices. Legal evidence from Romanian case law

no. $\mathrm{x}$ of December 18, 2012, was rejected. The court found that the Fiscal Inspection Report established additional tax obligations and related accessories, related to a tax base of 6,000 euros, respectively RON 35,769 for 2009 and decided to cancel the Decision no. 51 of June 21, 2013, and the additional payment obligations established by the Fiscal Inspection Report no. x of 18 December 2012. The Court force the defendant DRFP Brașov to pay part of the trial costs in favor of the applicant.

\section{The appeal}

Sentence no. 14 of February 4, 2016, pronounced by the Târgu Mureș Court of Appeal was appealed both by the plaintiff SC A. S.R.L, and by the defendant DRFP Brașov based on the provisions of art. 488 para. (1) points 6 and 8 of the Code of Civil Procedure, which stipulate:

,(1) The quashing of judgments may be sought only on the grounds of illegality:

6. when the decision does not include the grounds on which it is based or when it contains contradictory reasons or only reasons foreign to the nature of the case;

8. when the judgment was given in violation or misapplication of the rules of substantive law"

The criticisms brought by the appellant - plaintiff SC A. S.R.L

The appellant - plaintiff SC A. S.R.L appeals Sentence no. 14 of February 4, 2016, pronounced by the Târgu Mureș Court of Appeal bringing the following criticisms:

- canceling the Decision no. 51 of June 21, 2013, and the additional payment obligations established by the Fiscal Inspection Report no. x of 18 December 2012 is subject to interpretation due to the ambiguity and inaccuracy of the formulation, as it specifies only the tax base, respectively 6,000 euros and does not specify the amount of the tax liability, interest and penalties canceled;

- invoice no. $x$ of 2 November 2007 in the amount of RON 35,769 for 2007 issued by the plaintiff for the delivery of goods to $\mathrm{C}$. was erroneously taken over by the defendant in the tax base for 2009, and was included in deliveries to D., which led to a distorted calculation of the median, the margin of addition and implicitly of the additional tax and interest, penalties;

- in the commercial relations with the client, E. the tax bodies correctly applied the cost-plus method, but for determining the transfer prices in establishing the sample the provisions were not respected the legal norms considering the particularities of the traded goods, the volume of employed resources, and the 
Dumiter, F.C., Jimon, Ș.A. (2020)

Theoretical and practical assessments of transfer prices. Legal evidence from Romanian case law

value of intangible assets used, the contractual clauses and gave omitted the fact that the customer is an affiliated legal entity, which has partially provided the necessary materials in the production process.

Criticisms brought by the appellant - defendant DRFP Brașov

The appellant - defendant DRFP Braşov requested the quashing of the Sentence no. 14 of February 4, 2016, pronounced by the Târgu Mureș Court of Appeal and the exemption from the payment of court costs, motivating the action as follows:

- the value of the invoices issued by the affiliated company $D$. from Germany, representing services in the amount of EUR 6,000, cannot be considered deductible since customer B. from Germany did not intend to cancel the contract concluded with the appellant - plaintiff and renounce the purchase of products;

- the party that lost the trial may be obliged to bear the costs incurred by the trial only in the conditions of the existence of procedural fault and the sentence is final and irrevocable.

\section{The defenses in question}

The legal responsibility of the appellant - defendants DRFP Brașov

The appellant - defendant DRFP Brașov filed an objection to request the rejection of the appeal filed by the appellant - plaintiff SC A. S.R.L as unfounded. In the reasoning of the objection, the defendant claimed that it was specified in detail the additional payment obligations and their accessories, established by the tax authorities in relation to a tax base of 6,000 euros for 2009 , therefore there is no need to reiterate them.

Regarding the invoice no. $\mathrm{x}$ of 2 November 2007, the appellant-defendant argues its criticisms based on the address issued by the tax inspectorate showing that the results obtained by the appointed expert are different from those obtained by the tax authorities due to the use of a different computation method.

As regards intra-community trade relations, the defendant states that the main activity of the applicant SC ASRL is the production and marketing of household products in the category of gifts and design accessories for table decoration, as a result, the use of insignificant elements in the case would distort the conclusions of the analysis and it would have been inappropriate. Also, the transactions carried out by the two affiliated entities were not carried out at the level of the market ones, so that the control bodies adjusted the income of the appellant - plaintiff SC A. SRL related to the intra-community deliveries of goods to the affiliated company.

Legal response of the appellant - plaintiff SC A. S.R.L

12 Journal of Legal Studies Volume 26 Issue 40/2020

$\checkmark$ sciendo ISSN 2457-9017; Online ISSN 2392-7054.

Web: publicatii.uvvg.ro/index.php/jls. Pages $1-18$ 
Dumiter, F.C., Jimon, Ș.A. (2020)

Theoretical and practical assessments of transfer prices. Legal evidence from Romanian case law

The appeal filed by the appellant - plaintiff SC A. S.R.L requests the rejection of the appeal filed by the appellant - defendant DRFP Braşov as unfounded as the request for appeal does not exhaustively present the reasons for the appeal and lacks sufficient argumentation. Regarding the trial costs, the first instance ordered only their partial payment, according to art. 453 para. (1) and (2) of the Code of Civil Procedure:

„(1) The losing party shall be forced, at the request of the winning party, to pay its own costs.

(2) When the application has been admitted only in part, the judges shall determine the extent to which each of the parties may be ordered to pay the costs. If necessary, the judges will be able to order the compensation of the court costs."

Considerations of the High Court of Cassation and Justice of Romania regarding the actions of the parties

The considerations of the Court of Appeal regarding the appeal formulated by the appellant - the plaintiff SC A. S.R.L.

The High Court of Cassation and Justice of Romania admits the appeal filed by the plaintiff SC A. S.R.L against the Sentence no. 14 of February 4, 2016, pronounced by the Târgu Mureș Court of Appeal as being founded.

In the first ground of appeal, the appellant - plaintiff SC A. S.R.L criticizes the fact that the first instance does not specify in the sentence by which it decides to cancel the tax obligations related to the tax base of 6,000 Euro for 2009 the amount of the main tax liability and the number of related accessories. The Court of Appeal considers that this criticism is not a relevant argument, as the applicant's ambiguities can be clarified by requesting clarification to the court of the first instance.

The second ground of appeal relied on by the appellant - plaintiff SC A. S.R.L refers to invoice no. $x$ of November 2, 2007, to entity C., incorrectly retained by the tax authorities in 2009 as delivery to entity D., an error that distorted the amount of the median in determining the transfer prices. The High Court notes the procedural irregularity and notes that the invoice issued in 2007 should not be reflected in the 2009 tax base.

The last ground of appeal relied on by the applicant SC A. S.R.L. refers to the erroneous application of the substantive rules on the market price of intracommunity transactions between affiliated entities, claiming that the tax authorities did not take into account the particularities of the traded goods. The High Court notes that the tax authorities used the cost-plus method in determining transfer 
Dumiter, F.C., Jimon, Ș.A. (2020)

Theoretical and practical assessments of transfer prices. Legal evidence from Romanian case law

prices and formed the sample to determine the median level of transactions with independent external partner entities, including a large number of sales of stainless steel fireplace parts to customer E. The High Court considers that the inclusion in the sample of some products whose comparability has not been analyzed against their particularities, as well as the removal from the sample of transactions of a lower value, is not in accordance with the legal provisions.

The considerations of the Court of Appeal concerning the appeal of the appellant defendants DRFP Brașov

Following the examination of the appeal filed by the defendant DRFP Braşov and the documents of the case file, the High Court of Cassation and Justice of Romania considers the appeal filed by the appellant - defendant DRFP Braşov against Sentence no. 14 of February 4, 2016, pronounced by the Târgu Mureș Court of Appeal unfounded.

A critic of the appellant - defendant DRFP Brașov brought to the judgment of the court of the first instance argues the non-deductibility of expenses with consulting services provided by entity $\mathrm{D}$. in order to maintain business relations with client $\mathrm{B}$. The Court of Appeal notes that the defendant argues that the notification of the closure of the contract by client $\mathrm{B}$ does not produce effects in the conditions in which it was not accepted by the plaintiff SC A SRL. The court points out that the literature and legal practice allow the possibility of unilateral termination of contracts with successive execution, and the assumption of the tax authorities that the intervention of the consultant did not contribute to maintaining contractual relations between the two entities is not conclusive. As a result, the High Court upholds the first court's finding that the commission is deductible.

The appellant's criticism regarding the obligation to pay the trial costs is unfounded. Since the action was upheld in part, the court of the first instance determined that the applicant should be ordered to pay part of the costs, including the costs of the stamp duty, the partial fee for the expert opinion and the lawyer's partial fee. The High Court considers that the decision of the first instance is legal and sound.

The solution of the High Court of Cassation and Justice of Romania and the legal basis

The High Court considers the grounds of appeal invoked by the appellant - plaintiff SC A. S.R.L. as grounded, admits the appeal, quashes the Sentence no. 14 of February 4, 2016, pronounced by the Târgu Mureș Court of Appeal, and decides to partially cancel the contested documents and reduce the tax base to RON 702,793 
Dumiter, F.C., Jimon, Ș.A. (2020)

Theoretical and practical assessments of transfer prices. Legal evidence from Romanian case law

and the related profit tax to the amount of RON 112,447, amounts that take into account and correct the error made by including invoice no. $\mathrm{x}$ of November 2 , 2007 , on the basis of taxation of 2009. The Court upholds the decision of the court of the first instance on the additional tax obligations and their accessories, established for a tax base of 6,000 euros for 2009 and obliges the appellant defendant DRFP Brașov to payment of the amount of RON 2,000, representing court costs in favor of the appellant - plaintiff SC A. SRL.

The High Court rejects the appeal filed by the appellant - defendant DRFP Braşov against Sentence no. 14 of February 4, 2016, pronounced by the Târgu Mureș Court of Appeal, civil section II, of administrative and fiscal contentious in File no. $\mathrm{x} / 2013$ as unfounded.

\section{Conclusions}

The digitalization of the economy is one of the obstacles that transfer prices must overcome in the coming period. In this case, the taxation of multinational companies is the most sensitive aspect, with legal, economic and technical implications alike. However, we ask ourselves what does the digitalization of the economy mean, stricto sensu?! Certainly, the digitalization of the economy will involve the use of different economic and business information technologies in order to create added value but also in the recalibration of different economic models. Moreover, the creation of digital business models will have to involve certain elements such as customers, suppliers, financial and human capital, products, supply, and distribution chains.

In view of the above elements of the digitalization of the economy, national and international taxation will have to undergo such changes and refinements to meet the new requirements of the business environment. National tax systems will need to be adjusted to be flexible enough to allow for the establishment of the tax framework and the effective mechanism for setting them up. The allocation of taxation rights in the various tax jurisdictions will remain the cornerstone of taxation, the ultimate goal of their adjustment being, mutadis mutandis, to minimize double non-taxation of income and profits. In this sense, the type of electronic commerce (e-commerce) practiced by the big giants of the industry such as Amazon, Facebook, Google, Apple is particularly suggestive.

It should be noted the need to create a trade-off between the real economy and the digital economy; In this sense, the new business models developed by multinational companies must be targeted by BEPS but also by the improvement of the tax platforms offered by the tax authorities in various countries. Some companies have managed to develop businesses that have combined, through a perfect symbiosis, traditional business models with the new business models required by the digital economy, but also with the new IT \& $\mathrm{C}$ structures that have 
Dumiter, F.C., Jimon, Ș.A. (2020)

Theoretical and practical assessments of transfer prices. Legal evidence from Romanian case law

reached a very high level of development. Among these successful e-business solutions, we highlight fast online trading methods, financial betting, online payment and settlement services, cloud computing.

The case study presented highlights the fact that in Romania, currently, transfer prices have found their rightful place in national and international tax law. Both tax authorities and taxpayers are constantly seeking to continuously improve the methods and techniques of estimating and adjusting transfer prices. In recent years, in Romania, national legislation, represented by the fiscal code and the fiscal procedure code, has made remarkable progress in trying to lay a solid foundation for creating a stable framework for transfer prices and encouraging cross-border business.

In conclusion, we believe that there are certain challenges and prospects for transfer prices in the digital economy. First of all, establishing the digital presence of the enterprise on the territory of a state. Business management, coordination, development, and communication have improved significantly in recent years; therefore, when there is dematerialization of a company's digital activity, it will be much more difficult for tax authorities to frame for tax and fee purposes. Secondly, there is the issue of digital tax presence in business models, through different elements of identification and implementation. Finally, there is the issue of replacing the term "digital presence" with "significant presence", a term that is constructed to meet the chameleon-like nature of business relationships in business models.

\section{Acknowledgments}

The authors thank the anonymous reviewers and editor for their valuable contribution.

\section{Funding}

This research received no specific grant from any funding agency in the public, commercial, or not-for-profit sectors.

\section{Author Contributions}

FCD and ȘJ conceived the study and were responsible for the design and development of the conceptual framework. ȘJ was responsible for the judicial case collection and also for case study interpretation and analysis. FCD was responsible for the literature review section and the methodological aspects.

\section{Disclosure Statement}

The authors have not any competing financial, professional, or personal interests from other parties. 
Dumiter, F.C., Jimon, Ș.A. (2020)

Theoretical and practical assessments of transfer prices. Legal evidence from Romanian case law

\section{References}

1. Bilaney, S.K., (2014). Transfer Pricing in the Logistics Sector, International Transfer Pricing Journal, July/August 2014, pp. 236 - 240.

2. Buus, T., (2018). Risks and Transfer Pricing Regulation at the Multinational Enterprises' Routine Units: A Literature Review, Prague Economic Papers, pp. 1 - 16.

3. Dumiter, F., Boiță, M., (2017). Transfer Prices Implication upon Tax System. The Romanian Experience, Journal of Legal Studies, Vol. 19, Issue 33/2017, pp. 1 - 17.

4. Dumiter, F., Jimon, Ș., (2018). Taxation of Non-Resident Legal Entities in Romania. Case: RMMs vs. ANAF Brăila, Journal of Legal Studies, Vol. 21, Issue 35/2018, pp. 1 15.

5. Glahe, M., (2013). Transfer Pricing and EU Fundamental Freedoms, EC Tax Review, 5, pp. $222-232$.

6. Gouthiere, B., (2015). Recent Transfer Pricing Developments, European Taxation, February/March 2015, pp. $47-55$.

7. Koomen, M., (2015a). Transfer Pricing in a BEPS Era: Rethinking the Arm's Length Principle - Part I, International Transfer Prices Journal, May/June 2015, pp. 141 - 152.

8. Koomen, M., (2015b). Transfer Pricing in a BEPS Era: Rethinking the Arm's Length Principle - Part II, International Transfer Prices Journal, July/August 2015, pp. 230 - 244.

9. Rossing, C.P., Pearson, T.C., (2014). Transfer Pricing Knowledge Management, International Transfer Pricing Journal, July/August 2014, pp. 264 - 274.

10. Rossing, C.P., Pearson, T.C., Nesimi, A., (2016). Strategic Control of Transfer Pricing in a BEPS Context, International Transfer Pricing Journal, May/June 2016, pp. 223 - 231.

11. Sim, S., (2013). Transfer Pricing Issues in Financial Services, Asia - Pacific Tax Bulletin, May/June 2013, pp. 215 - 218.

12. Stana, G.B., Turlea, I.C., (2017). Risk Estimation of Romanian Large Taxpayers based on Transfer Pricing Analysis, Economic Computation and Cybernetics Studies and Research, Issue 3/2017, Vol. 51, pp. $281-298$.

13. Stork, A., Petruzzi, R., Pankiv, M., Tavares, R.J.S., (2016). Global Transfer Pricing Conference "Transfer Pricing in a Post-BEPS World", International Transfer Pricing Journal, May/June 2016, pp. 216 - 222.

14. Wright, D.R., Keates, H.A., Lewis, J., Auten, L., (2016). The BEPS Action 8 Final Report: Comments for Economists, International Transfer Pricing Journal, March/April 2016 , pp. $99-108$.

15. *** Law no. 207/2015 on the Fiscal Procedure Code, with subsequent amendments and completions.

16. *** Law no. 227/2015 on the Fiscal Code, with subsequent amendments and completions, including its Implementing Rules.

17. *** Law no. $241 / 2005$ for preventing and combating tax evasion, with subsequent amendments and completions.

18. *** Law no. 571/2003 on the Fiscal Code, with subsequent amendments and completions, including its Implementing Rules.

19. *** O.G. no. 92/2003 on the Fiscal Procedure Code, republished, with subsequent amendments and completions, including its Implementing Rules. 
Dumiter, F.C., Jimon, Ș.A. (2020)

Theoretical and practical assessments of transfer prices. Legal evidence from Romanian case law 20.*** Order no. 222/2008 of February 8, 2008, regarding the content of the transfer prices file.

21. *** Order no. 2309/2017 of 1 August 2017 amending the Order of the President of the National Agency for Fiscal Administration no. 3.626 / 2016 establishing the list of reporting jurisdictions with which Romania will cooperate based on the Multilateral Agreement of Competent Authorities for Automatic Exchange of Information on Financial Accounts, the List of Non-Ferrous Financial Institutions, and the Excluded Accounts List, provided in the legal instruments of international law to which Romania has engaged in the automatic exchange of financial information, published in Official Gazette no. 635 of 3 August 2017. 